\title{
GUIDELINES TO FACILITATE THE NURSING ACCOMPANIMENT OF MOTHERS WITH INFANTS IN A NEONATAL INTENSIVE CARE UNIT
}

\author{
Dalena van Rooyen \\ D Cur \\ Professor of Nursing, Nelson Mandela Metropolitan University, Port Elizabeth \\ Corresponding author: dalena.vanrooyen@nmmu.ac.za
}

\section{Zoliswa L Nomgqokwana \\ M Cur \\ Unit Manager, St George's Hospital, Port Elizabeth}

\author{
Wilma J Kotzé \\ D Cur \\ Emeritus Professor of Nursing, Nelson Mandela Metropolitan University, Port Elizabeth
}

\section{Sheree Carlson \\ D Cur}

Senior Lecturer, School of Nursing Science, Nelson Mandela Metropolitan University, Port Elizabeth

Keywords: mother; infant; neonatal intensive care unit; registered nurse; accompaniment

\begin{abstract}
To be the mother of a premature infant in a neonatal intensive care unit can sometimes be overwhelming. The hospital environment and the sound made by the life support apparatus in the unit may be terrifying for persons who are unfamiliar with this environment. An observation of the researcher, who practises in a neonatal intensive care unit, was that mothers were often very distressed after the admission of their infants. It also appeared as if health care practitioners were failing to provide for the needs of these mothers. The objectives of the research on which this article is based were: firstly, to acknowledge and describe the experiences of the mothers with regard to the hospitalisation of their infants in the neonatal intensive care unit and secondly, to utilise the information obtained to develop guidelines to assist registered nurses accompanying mothers throughout their infants'stay in the neonatal intensive care unit. The conclusion was reached that mothers whose infants are admitted to the neonatal intensive care unit have a need for compassionate accompaniment by registered nurses during the period of hospitalisation of their infants.
\end{abstract}

\section{OPSOMMING}

Om moeder van 'n premature baba in die neonatale intensiewesorgeenheid te wees, is dikwels oorweldigend. Die hospitaalomgewing en die geluide wat deur lewensondersteunende apparate in die eenheid gemaak word is vir persone wat dit nie ken nie, vreesaanjaend. Die navorser, wat in die neonatale intesiewesorgeenheid praktiseer, het waargeneem dat die moeders van babas uiters ontsteld is na die toelating van hulle babas tot die neonatale intensiewesorgeenheid. Dit het ook voorgekom asof die gesondheidsdienspraktisyns nie in die belangrikste behoeftes van hierdie moeders voorsien nie. Die doelwitte van die navorsing waaroor in hierdie artikel verslag gedoen word was: eerstens, om die belewinge van die moeders te verken en te beskryf met betrekking tot die hospitalisering van hulle babas in die neonatale intensiewesorgeenheid en tweedens, om inligting wat só verkry is, te gebruik om riglyne vir geregistreerde verpleegkundiges te ontwikkel ten opsigte van die begeleiding van moeders wie se babas in die neonatale intensiewesorgeenheid opgeneem is. Daar is tot die slotsom gekom dat moeders wie se babas in die neonatale intensiewesorgeenhied gehospitaliseer is, ' $n$ behoefte het aan deernisvolle begeleiding deur die 
geregistreerde verpleegkundiges tydens hulle babas se hospitalisering.

\section{INTRODUCTION}

The purpose of this article is to describe the results of a study that was conducted to develop guidelines for registered nurses to optimally accompany mothers whose infants have been admitted to a neonatal intensive care unit. These mothers fall within the ambit of family members with special needs who require nursing accompaniment during these stressful events in their lives. The nurses' involvement in this regard stems from their fundamental responsibilities to promote health, prevent illness, restore health and alleviate suffering. As the need for nursing care is universal, nurses are to render health services to these mothers as individuals, as family members and as community members, and they need to co-ordinate their services with those of related service providers should these needs arise (Callery, 1997:27).

\section{PROBLEM STATEMENT}

The admission of an infant to a neonatal intensive care unit is stressful to parents. The environment is highly specialised and can be a frightening place due to the level of technology present. An infant may be connected to a ventilator to facilitate breathing until there is evidence of an improvement in his/her condition and normal functioning, independently from the life-support system, is possible. Parents also experience concern due to the costs involved in neonatal intensive care. Although it is commonly accepted that mothers are experts regarding their children, limited research has been conducted into the nature of these mothers' experiences relating to the illness of their infants (Tiedeman, 1997:110).

The researcher, who practises in a neonatal intensive care unit, noticed that mothers of hospitalised infants were visibly distressed and anxious after admission of their infants to the unit. This concern, in a broader sense, also reverberated on radio-talk shows where mothers indicated that they were given insufficient information regarding the admission of their infants to hospital. The researcher has frequently met concerned mothers who had to leave their infants in the intensive care unit because of illness. Their distress has perturbed the re- searcher throughout her nursing career and has prompted her to investigate this phenomenon by looking at the nature of the relationship of parents with their newborn babies, the nature of the neonatal intensive care unit and the role of the intensive care nurse.

\section{DEFINITION OF CONCEPTS}

Mother: A woman in relation to a child or children to whom she has given birth. It includes a woman who has the care of a child through adoption (South African Concise English Dictionary, 2002:758).

Infant: An infant is a very young child or a baby incapable of any form of independence from their mother; usually a child under the age of one year, especially a newborn child (South African Concise English Dictionary, 2002:590).

Neonatal intensive care unit: The neonatal intensive care unit is an area within a health care institution where only specialised health personnel provide care to sick infants requiring close monitoring via highly sophisticated technological equipment (Klein, Alan \& Canon, 1998:28).

Registered Nurse: Section 16 of the Nursing Act, 1978 (Act 50 of 1978), as amended, defines the registered nurse as a person who is authorised to practice nursing or midwifery in his/her own right. In terms of the Act, such a person will have complied with the training required for registration with the South African Nursing Council as a nurse or midwife (Nursing Act 50 of 1978).

Accompaniment: Is a planned and a deliberate intervention executed according to the needs of an individual, and is aimed at inducing self-reliance in that individual (Kotzè, 1998:10).

\section{RESEARCH QUESTIONS}

Resulting from the research problem, the following research questions were formulated for the research:

- How do mothers experience the hospitalisation of their infants in the neonatal intensive care unit? 
- What information should be provided in guidelines for registered nurses to accompany these mothers effectively?

\section{RESEARCH OBJECTIVES}

The objectives of the study were to:

- explore and describe the mothers' experiences related to the hospitalisation of their infants in a neonatal intensive care unit; and

- develop guidelines to assist registered nurses accompanying mothers throughout their infants' stay in a neonatal intensive care unit.

\section{RESEARCH DESIGN AND METHOD}

\section{Research Design}

The researcher embarked upon a two phase qualitative, phenomenological, explorative, descriptive and contextual study into the experiences of mothers relating to the hospitalisation of their infants in the neonatal intensive care unit. During phase one, mothers' experiences relating to the hospitalisation of their infants in the neonatal intensive care unit were explored and described. Phase two involved the interpretation of data and the development of guidelines to ensure optimal accompaniment of these mothers by registered nurses in the neonatal intensive care unit.

\section{Sample population and method}

The population in this study comprised mothers whose infants were hospitalised in the neonatal intensive care unit. The target population identified in the study comprised mothers whose infants had been hospitalised for more than three days in the neonatal intensive care unit in which the researcher was working. Consequently, purposive sampling was used. As Burns and Grove (1999:475) indicate, purposive sampling entails judgmental sampling that involves the conscious selection, by the researcher, of certain subjects or elements to include in a study. Interviews were conducted until the researcher presumed that data were saturated. The independent coder who analysed and coded the transcribed interviews confirmed data saturation. Streubert and Carpenter (1995:24) define saturation as a term that refers to repetition of discovered information.

\section{Method of data collection}

Data were gathered by means of phenomenological interviews in an environment that the researcher ensured was conducive to interviewing. The phenomenological approach is an inductive approach to enquiry that attempts to describe the experiences as they are lived by the participants (Burns \& Grove, 1997:14).

An audiotape recorder was utilised to capture interviews. These interviews were transcribed verbatim afterwards. Directly following each interview, field notes were made about situational factors relating to the interview. The central research question put to each mother was: "How did/do you experience the hospitalisation of your infant in the neonatal intensive care unit?'

The researcher utilised the first interview as a pilot interview to assess the feasibility of the proposed question and to detect possible flaws in the question. The research question remained unchanged as it was clearly understood and elicited data as expected.

\section{Data analysis}

Interviews were transcribed verbatim. The researcher and the independent coder analysed data, according to Tesch's method of data analysis (in Creswell, 1994:155), for the emergence of themes that were prevalent and best told the story of the experiences of mothers' with infants in a neonatal intensive care unit. Raw data were reduced until the central storyline, as told by the mothers, emerged clearly. A meeting was held between the researcher and the independent coder to reach consensus on the storyline and themes.

\section{Literature control}

Once the data analysis was completed, literature was reviewed to place the findings within the context of what was already known about the topic.

\section{TRUSTWORTHINESS}

Guba's model (in Krefting, 1991:215) was utilised to 
ensure the trustworthiness of this study. This model suggests different strategies of assessing criteria important to researchers in securing rigor in qualitative studies and for readers to use as a means of assessing the value of findings of qualitative research. The researcher's application hereof is contained in Table 1.

Table 1: Strategies to ensure trustworthiness

\begin{tabular}{|c|c|c|c|}
\hline Criteria & Strategy & Actions & Application criteria \\
\hline \multirow[t]{3}{*}{ Truth value } & Credibility & $\begin{array}{l}\text { Prolonged and } \\
\text { varied field } \\
\text { experience }\end{array}$ & $\begin{array}{l}\text { Prolonged engagement through extended } \\
\text { practising in the area in which the } \\
\text { phenomenon under study revealed itself and } \\
\text { through conducting phenomenological } \\
\text { interviews until data were saturated. }\end{array}$ \\
\hline & & $\begin{array}{l}\text { Authority of } \\
\text { the researcher }\end{array}$ & $\begin{array}{l}\text { The authority of the researcher was verified } \\
\text { through supervision by two senior lecturers } \\
\text { (well acquainted with qualitative research) } \\
\text { from a university. In addition, the researcher } \\
\text { has undergone specific training in research } \\
\text { methodology. }\end{array}$ \\
\hline & & $\begin{array}{l}\text { Triangulation } \\
\text { of data } \\
\text { sources }\end{array}$ & $\begin{array}{l}\text { A literature control was conducted using } \\
\text { similar studies done on experiences of } \\
\text { mothers with infants hospitalised in neonatal } \\
\text { intensive care units. }\end{array}$ \\
\hline \multirow[t]{2}{*}{ Applicability } & Transferability & $\begin{array}{l}\text { Nominated } \\
\text { sample }\end{array}$ & $\begin{array}{l}\text { The sampling method was purposive and } \\
\text { included a specific population group. }\end{array}$ \\
\hline & & $\begin{array}{l}\text { Dense } \\
\text { description }\end{array}$ & $\begin{array}{l}\text { A complete description of the research } \\
\text { design and methodology was given. } \\
\text { Literature control preserved transparency } \\
\text { and all interviews were analysed to ascertain } \\
\text { clarity. }\end{array}$ \\
\hline \multirow[t]{2}{*}{ Consistency } & Dependability & $\begin{array}{l}\text { Dense } \\
\text { description }\end{array}$ & The research method was fully described. \\
\hline & & $\begin{array}{l}\text { Code-recode } \\
\text { procedure }\end{array}$ & $\begin{array}{l}\text { A consensus discussion was held between } \\
\text { the researcher and an independent coder. } \\
\text { Research was conducted under guidance of } \\
\text { two supervisors with appropriate expertise. }\end{array}$ \\
\hline Confirmability & & Audit trail & $\begin{array}{l}\text { An independent coder, who is an expert in } \\
\text { the field of qualitative research, did an } \\
\text { independent examination of the data. }\end{array}$ \\
\hline
\end{tabular}




\section{ETHICAL CONSIDERATIONS}

The ethical principles stated by De Vos (1998:24) were considered throughout the research study. These include privacy and confidentiality, protection of research participants and informed consent.

\section{Privacy and Confidentiality}

Information shared by the mothers was not made available to any person/s. All information was destroyed on completion of the study. The tapes were erased and transcribed notes were made available to the independent coder only. No names appeared on any documentation.

\section{Protection of Research Participants}

The participants were informed beforehand about the reason for the study and had the full right to withdraw from it at any time. However, all participants persevered throughout the study. The study prompted the sharing of emotions and tensions experienced by the mothers. To make provision for the supporting of these mothers, (prior to, during and after interviews) they were given the details of a counselor who is available to help with these issues if needed. Arrangements were made for this prior to the interviews.

\section{Informed Consent}

Informed consent was obtained from all participants prior to the interviews, as well as the Nursing Service Manager and the Hospital Manager of the private institution utilised in the study.

\section{Scientific Integrity of the Researcher}

The researcher adhered to scientific integrity via actions which operationalised the strategies set for the different criteria as explicated in Guba and Lincoln's model for trustworthiness (in Krefting, 1991:215). In addition, the researcher did not fabricate any findings. An independent coder, as well as the two supervisors, confirmed all themes and sub-themes.

\section{OUTLINE OF THE RESULTS}

Two central themes were identified from the data on mothers' experiences of the stay of their infants in the neonatal intensive care unit. An outline of these themes and their accompanying sub-themes is contained in Table 2.

\section{DISCUSSION OF THE RESULTS}

\section{Theme 1: The Mothers' Experiences Re- lated to their Infants' Admission and Stay in a Neonatal Intensive Care Unit}

In the neonatal intensive care unit the mother is faced with a fragile newborn with an overwhelming array of needs. She is consequently shocked and terrified and begins to grieve losses that she may be unable to express verbally. Benfield (1996:7090) likens the experience of a mother with a premature infant, artificially ventilated in a neonatal intensive care unit, to an emotional roller-coaster ride that includes anticipatory grief - hoping that the infant will survive while, simultaneously, preparing for its death.

\section{Sub-theme 1.1: The mother experienced various emotions regarding her infant's admission and stay in the neonatal inten- sive care unit}

The emotions described by the mother's admission of an infant to the neonatal intensive care unit suggest a state of shock. During the interviews mothers pertinently stated that "it was a terrible shock because I never expected this to happen to me".

Fear that the infant may die was experienced. As one mother stated, "I was so frightened, that I hated coming to the unit. Every time I was supposed to come, I had a tight feeling in my stomach, because every time the machine made a noise I thought my baby is dying".

Anxiousness about all aspects surrounding the infant's condition and situation were experienced. Kaplan and Saddock (1998:389) claim that anxiety is an unpleasurable emotional state associated with psychological changes in response to intrapsychic conflict. As a mother put it, "When you enter the neonatal intensive care unit and the nurse looks at you and says she has some bad news for you, you are so anxious you do not know what to expect". 
Feelings of anger at prematurity, and particularly the size of the infant, were also experienced. One mother said: "When I saw how small my baby was, I was very angry. I did not want to look at it, did not want to touch it ... I had no idea what a 1,3 kg baby looked like - I wanted to run away and never come back".

The mothers experienced frustration with the risk attached to the weakness and helplessness of the infant. Harvey (1999:84) states that the birth of a preterm baby is an emotional crisis for the mother. One participant shared "When I got to see my baby ... I saw my baby lying there, sick and looking helpless ... I didn't know what to do ... he was so weak'. The admission of the infant to the neonatal intensive care unit can evoke feelings of frustration that can impinge on the early mother-child relationship, even resulting in long lasting effects.

Mothers felt that there was a lot they wanted to do but they were unable to help with the care of the infant. Helplessness at not being able to personally and independently manage and nurse the infant was experienced. The following quote supports this statement: "As a mother, you see your baby lying there. There is a lot you personally want to do to help but you cannot ... I feel by not talking to your baby, you do not really bond. You need to be able to do something like help with washing your baby, or change the nappy then you feel happy that you are nursing your baby".

Feelings of guilt and failure were also experienced. Mothers experienced guilt feelings that they could not carry the pregnancy to term, so they blamed themselves as mothers and, thus, felt more guilty than the fathers. This is evident from the following quotes: "I feel so guilty when I look at my baby. I kept on asking myself why could I not carry this pregnancy to term?" and "This is the time to be truthful. It's been a nightmare. I felt so guilty, looking at my baby lying there; not knowing why one delivers before the time. You feel guilty even signing papers letting the doctors and nurses do anything they can do to help him. You really feel guilty'. These guilt feelings resulted in the mothers feeling that they were failures.

\section{Sub-theme 1.2: The mother's experiences of staff}

These experiences related to the nurses and medical practitioners and included both positive and negative experiences. These experiences are described as follows:

\section{Experiences relating to the nurses}

Mothers had positive experiences relating to the nurses such as:

- Perceiving nurses to be competent in what they were doing and competent as a source of information. Mothers were complimentary to nursing staff and thankful to them. They said: "I think sometimes we parents are not thankful enough, like yesterday there was a mother with lots of complaints about nursing staff. I said no, no these nurses are doing a good job... they tell you everything you want to know". Holloway (1993:15) states that the process of caring for individuals, for families and for groups is a major focus in nursing today. Caring in nursing is a powerful force that involves the nurse, the patient and the environment. Caring requires a tremendous body of knowledge, commitment, clear human values and personal, social and moral engagement of the nurse.

Mothers had negative experiences relating to the nurses such as:

- Perceiving some nurses as not being adequately supportive. This is evident in the following quote: "For the nurse to say everything is okay, means nothing for me. I work in a building industry and I know nothing about nursing. The nurse must not be tired of explaining everything to us. She must explain exactly what she means by saying everything is okay'. Gibbins and Chapman (1996:148) state that nurses in the neonatal intensive care unit have a responsibility to answer the parents' questions truthfully and to be sensitive to parental perceptions of the unit to better facilitate a positive experience.

\section{Experiences relating to the medical practitioners} Mothers experienced the medical practitioners as:

- Not being honest regarding the infant's condition. A mother stated she did not 
Table 2: Main themes and sub-themes on the experiences of mothers with infants in a neonatal intensive care unit

\begin{tabular}{|c|c|}
\hline Main themes & Sub-themes \\
\hline $\begin{array}{l}\text { 1. Mothers' experiences } \\
\text { related to their infants' } \\
\text { admission and stay in the } \\
\text { neonatal intensive care unit }\end{array}$ & $\begin{array}{l}\text { 1.1 The mothers experienced various emotions regarding their } \\
\text { infants' admission and stay in the neonatal intensive care } \\
\text { unit: } \\
\text { 1.1.1 Shock on the infant's admission to the neonatal intensive } \\
\text { care unit. } \\
\text { 1.1.2 Fear that the infant may die. } \\
\text { 1.1.3 Anxiousness about all aspects surrounding the infant. } \\
\text { 1.1.4 Anger at the prematurity, and particularly the size, of the } \\
\text { infant. } \\
\text { 1.1.5 Frustration with the risk attached to the weakness of the } \\
\text { infant. } \\
\text { 1.1.6 Helplessness at not being able to personally and } \\
\text { independently manage and nurse the infant. } \\
\text { 1.1.7 Feelings of guilt and failure. } \\
\text { 1.2.1 Nurses: } \\
\text { - Positive experiences } \\
\text { 1.2.1.1 Perceived nurses as competent and a source of } \\
\text { information. } \\
\text { 1.2. } \\
\text { 1.2.1.2 Pegative experiences } \\
\text { 1.2.2. Perceived some nurses as not being adequately } \\
\text { treatment and progress to parents. }\end{array}$ \\
\hline $\begin{array}{l}\text { 2. Mothers' experiences of } \\
\text { the neonatal intensive care } \\
\text { environment }\end{array}$ & $\begin{array}{l}\text { 2.1 The mothers experienced the physical environment as: } \\
\text { 2.1.1 Threatening: } \\
\text { - Unfamiliar with foreign sounds. } \\
\text { - Unfriendly. } \\
\text { 2.2 The mother experienced an acute lack of personal } \\
\text { knowledge and comprehension related to: } \\
\text { 2.2.1 The infant's dependence on life support technology. } \\
\text { 2.2.2 Routines and policies of the neonatal intensive care unit. }\end{array}$ \\
\hline
\end{tabular}


"want to be shielded from information concerning her infant's condition". They expected honest information and yet it was not what they received. They wanted direct answers to their questions. Maroney and O'Brien (1999:3) state that doctors and nurses should respect the parents enough to allow them to feel all their jumbled emotions without running away or mini-mising what they feel.

- Inadequately available to explain treatment and progress to parents. Mothers felt that doctors should make time, set up an appointment with both parents, sit down and explain the condition of the baby to them. However, this is not happening according to the following quote: "I think maybe the doctors must be more available ... never at any stage did they sit down and talk to you ... they make the final decisions".

\section{Theme 2: The Mothers' Experiences of the Neonatal Intensive Care environment}

\section{Sub-theme 2.1: The mothers' experiences of the physical environment}

The mothers experienced the physical environment of the neonatal intensive care unit as being threatening, unfamiliar with foreign sounds as well as unfriendly. Clochesy, Breu, Cardin, Whittaker and Rudy (1996:89) state that the technologic critical care environment offers numerous benefits to the critically ill patient and family including increased survival and prompt intervention, which often achieve dramatic results. However, they state further that these well-recognised benefits are accompanied by severe physical and psychological burdens and that these phenomena have been of interest to many researchers.

\section{Sub-theme 2.2: The mother experienced an acute lack of personal knowledge and comprehension}

The mother experienced an acute lack of personal knowledge and comprehension relating to the infant's dependence on life support technology. Mothers need to know the purpose of instruments used and tests done on the infant. The following statement revealed this need for knowledge: "I felt intimidated in the unit, I really think maybe a tour would have been wonderful.
A tour would have enabled us to realise that those monitoring things were basically for monitoring purposes". Maroney and O'Brein (1999:2) support this by stating that parents of infants in the neonatal intensive care unit must be given complete information that is significant and all reasons for investigations and tests should be explained in terms that parents can understand.

Mothers experienced an acute lack of personal knowledge and comprehension about the routines and policies of the neonatal intensive care unit. The mothers said that they and their parents were unhappy with these and wanted to know the reason for the policies. A mother stated: "The thing that I experienced that was quite upsetting to them (parents) was the fact that my parents, who live far away, could only visit once a week and I really needed them there all the time". It is, therefore, imperative that nurses take the time to explain unit policies and procedures to anxious parents of newborn babies in critical care units.

\section{GUIDELINES FOR REGISTERED NURS- ES TO ACCOMPANY MOTHERS WITH IN- FANTS IN THE NEONATAL INTENSIVE CARE UNIT}

Based on the findings, guidelines were developed on the premise of establishing and maintaining a therapeutic relationship with mothers to facilitate their nursing accompaniment whilst their infants are in a neonatal intensive care unit. The guidelines are summarised in Table 3.

\section{Discussion of Guidelines}

The focus of the guidelines is on the accompaniment of mothers with infants in the neonatal intensive care unit.

\section{Establishing and maintaining a thera- peutic relationship}

- Enhance a sense of security in parents, especially mothers, of infants admitted to the neonatal intensive care unit.

The registered nurse does this by:

- Making each mother feel welcome on arrival in the unit and taking time to sit and listen to her. 
Table 3: Guidelines for establishing and maintaining a therapeutic relationship and a therapeutic milieu to accompany mothers with infants in a neonatal intensive care unit

\begin{tabular}{|c|c|}
\hline $\begin{array}{l}\text { 1. Establishing and maintaining a } \\
\text { therapeutic relationship }\end{array}$ & $\begin{array}{l}\text { The registered nurse needs to: } \\
\text { - } \quad \text { Enhance a sense of security in parents of } \\
\text { infants admitted to the neonatal intensive } \\
\text { care unit. } \\
\text { Establish trust through acceptance and } \\
\text { respect. }\end{array}$ \\
\hline $\begin{array}{l}\text { 2. Establishing and maintaining a therapeutic } \\
\text { milieu }\end{array}$ & $\begin{array}{l}\text { The registered nurse needs to: } \\
\text { - Inform the mother at all times of activities } \\
\text { and procedures. } \\
\text { - } \quad \text { Provide honest information and clear } \\
\text { explanations. }\end{array}$ \\
\hline
\end{tabular}

- Involving the mother with as many activities as possible related to the care of her infant.

- Allowing the mother to do things on her own (such as changing a napkin, cleaning the buttocks).

- Informing the mother that she/he is available whenever she needs assistance and advice.

- Giving as much information as possible to the mother about the condition of her infant.

- Establish trust through acceptance and respect.

The registered nurse needs to:

- Be deliberately and intentionally aware of the importance of securing and creating privacy and sensitivity to the needs of the mother when spending time with her infant.

- Allow mothers to express their feelings, needs and fears.

- Explore the needs of parents, especially mothers, in their taking over of caring for their infant after discharged from the unit.

- Encourage mothers to focus on the strengths and potential strengths of the infant instead of fixating on the weakness and vulnerability of the infant.
- Provide support without making judgments.

- Promote bonding between the infant and the mother.

- Parents need to develop trust in the nurse and this is facilitated through their:

- Observation of the registered nurse's competence, her timely and accurate interventions and confident conduct as a mature and professional person.

- Experiencing her protective and warm attitude, her advocacy on their behalf, her willingness to assist, her availability and, particularly, the time and attention she gives the mothers to listen to them and assist them.

\section{Establishing and maintaining a thera- peutic milieu}

The registered nurse needs to:

- Inform the mother at all times of activities and procedures:

- The routine of the unit, as well as oriented briefly (in a manner that she understands) to the use of equipment used on her infant. Use can be made of a "parent library" with as much information as possible such as updated textbooks, videos, pamphlets and websites. 
- The communication systems in the unit, for example who to call when help is needed.

- The rules of the unit, for example, the importance of hand washing, and the reasons for controlling the number of visitors to the unit.

- Provide honest information and clear explanations.

\section{LIMITATIONS}

The following limitations while gathering data for the study were identified:

- $\quad$ The fathers were not available to be interviewed.

- $\quad$ The scope of the study was limited to a neonatal intensive care unit in a private hospital. The study does not include experiences of mothers whose infants are hospitalised in neonatal intensive care units in state hospitals.

\section{CONCLUSION}

The researcher realised, through this study, that mothers of infants admitted to the neonatal intensive care unit experience a variety of emotions. The purpose of the study was to observe, explore and describe the mothers' experiences related to the hospitalisation of their infants in the neonatal intensive care unit and to develop guidelines to assist registered nurses in accompanying these mothers throughout their infants stay in the neonatal intensive care unit. Through the literature study the experiences identified by the researcher were confirmed as universal and the feelings deduced as natural.

\section{BIBLIOGRAPHY}

BENFIELD, C 1996: Comparing the anticipatory grief response of mothers and fathers in a neonatal intensive care setting. Dissertation Abstracts, 56(12):7090-7091.

BURNS, N \& GROVE, SK 1997: The practice of nursing research: Conduct, critique and utilization. Philadelphia: WD Saunders. BURNS, N \& GROVE, SK 1999: Understanding nursing research; $2^{\text {nd }}$ edition. Philadelphia: WD Saunders.

CALLERY, N 1997: Shared case: A partnership between parents and nurses. International Journal of Nursing, 8(11):27-34. CLOCHESY, J; BREU, C; CARDIN, S; WHITTAKER, A \& RUDY, E
1996: Critical care nursing. Philadelphia: WD Saunders.

CRESWELL, JW 1994: Research design. Qualitative and quantitative approach. Thousand Oaks: Sage.

DE VOS, AS 1998: Research at grass roots. A primer for the caring professions. Pretoria: Van Schaik.

GIBBINS, S \& CHAPMAN, J 1996: Holding on - parents' perception of premature infant's transfers. Journal of Obstetrics, Gynaecology and Neonatal Nursing, 25(2):147-153.

HARVEY, D 1999: Parental visiting, communication and participation: A comparison of neonatal unit policies in Europe. London: Royal College of Paediatrics.

HOLLOWAY, I 1993: Nursing the critically ill adult. California: Addison-Wesley.

KAPLAN, H \& SADDOCK, B 1998: Synopsis of psychiatry, behavioural sciences, clinical psychiatry. London: Williams \& Wilkins.

KLEIN, M; ALAN, H \& CANON, J 1998: Caring for your premature baby: A complete resource for parents. New York: Library of Congress.

KOTZÉ, WJ 1998: An anthropological nursing science nursing accompaniment theory. Health SA Gesondheid, 3(2):3-14.

KREFTING, L 1991: Rigor in qualitative research. The assessment of trustworthiness. American Journal of Occupational Therapy, 45(3):214-222.

MARONEY, D \& O'BREIN, A 1999: The experience of parenting a premature infant in the neonatal unit is often overwhelming. http:/ /www.preemie-L.org/. (Accessed: November 2000).

SOUTH AFRICAN 1978: The Nursing Act, 1978 (Act 50 of 1978) as amended. Pretoria: Government Printer.

SOUTH AFRICAN CONCISE ENGLISH DICTIONARY 2002: Oxford: Clarendon Press.

STREUBERT, T \& CARPENTER, D 1995: Qualitative research in nursing: Advancing the humanistic imperative. Philadelphia: Lippincott.

TIEDEMAN, WE 1997: Anxiety responses of parents during and after hospitalization of their infants. Journal of Paediatric Nursing, 12(2):110. 